Vol. 8(12), pp. 1277-1281, 19 March, 2014

DOI: 10.5897/AJ MR2014.6613

ISSN 1996-0808

Copyright (c) 2014

African Journal of Microbiology Research

Author(s) retain the copyright of this article

http://www.academicjoumals.org/AJ MR

\title{
Phylotype analysis of Ralstonia solanacearum strains causing potato bacterial wilt in Karnataka in India
}

\author{
Vinay Sagar ${ }^{1 *}$, Malkhan Singh Gurjar ${ }^{2}$, Jeevalatha Arjunan ${ }^{1}$, Rahul R. Bakade ${ }^{3}$, S. K. \\ Chakrabarti $^{5}$, R. K. Arora ${ }^{4}$ and Sanjeev Sharma ${ }^{1}$ \\ ${ }^{1}$ Central Potato Research Institute, Shimla-171 001.Himachal Pradesh, India. \\ ${ }^{2}$ Central Potato Research Station, Shillong-793 009, Meghalaya, India. \\ ${ }^{3}$ Central Potato Research Station, Patna-801 506, Bihar, India. \\ ${ }^{4}$ Central Potato Research Station, Jalandhar-144 003,Punjab, India. \\ ${ }^{5}$ Central Tuber Crops Research Institute, Thiruvananthapuram-695 017, Kerala, India.
}

Received 8 January, 2014; Accepted 21 February, 2014

\begin{abstract}
Potato is one of the important cash crop of Karnataka (India) farmers and there is a tremendous scope to increase the area and productivity of this crop in the state. However, this crop is badly affected by bacterial wilt disease caused by Ralstonia solanacearum especially in Hassan, Chikmagalur and Bengaluru districts. During Kharif 2011 season, a total of fifteen bacterial strains were recovered from stem pieces of wilting potato plants collected from potato growing regions of Hassan and Chikmagalur districts in Karnataka. Total genomic DNA was extracted and the identity of all the fifteen strains was confirmed as $R$. solanacearum as expected single 280 -bp fragment resulted in all the isolates following polymerase chain reaction (PCR) amplification using the $R$. solanacearum specific universal primer pair 759/760. A phylotype specific multiplex PCR revealed that all the bacterial strains belonged to phylotype I of $R$. solanacearum which correspond to race 1 of the pathogen.
\end{abstract}

Key words: Bacterial wilt, Karnataka, phylotype, potato, Ralstonia solanacearum.

\section{INTRODUCTION}

Potato (Solanum tuberosum L.) occupies an area of about 76.8 thousand ha with a total production of 788 thousand tonnes in Karnataka. Among the six potato growing districts, Hassan district alone contributes more than $50 \%$ of area and potato production in Karnataka. It is one of the important cash crop of Karnataka farmers, and there is a tremendous scope to increase the area and productivity of this crop in the state (Basvaraja et al., 2009). However, potato production is adversely affected by bacterial wilt disease especially in Hassan, Chikmagalur and Bengaluru districts (Anonymous, 2011).

Bacterial wilt (brown rot) incited by Ralstonia solanacearum (Yabuuchi et al., 1995) is a major constraint on potato production worldwide and in many potato growing regions of India (Elphinstone, 2005; Sagar et al., 2014). Historically, $R$. solanacearum has been divided into five races related to the ability to wilt members of the family Solanaceae (race 1), banana

${ }^{*}$ Corressponding author. E-mail: vsagar.cpri@gmail.com. Tel: +91 177 2624575. Fax: +91 1772624460.

Author(s) agree that this article remain permanently open access under the terms of the Creative Commons Attribution License 4.0 International License 


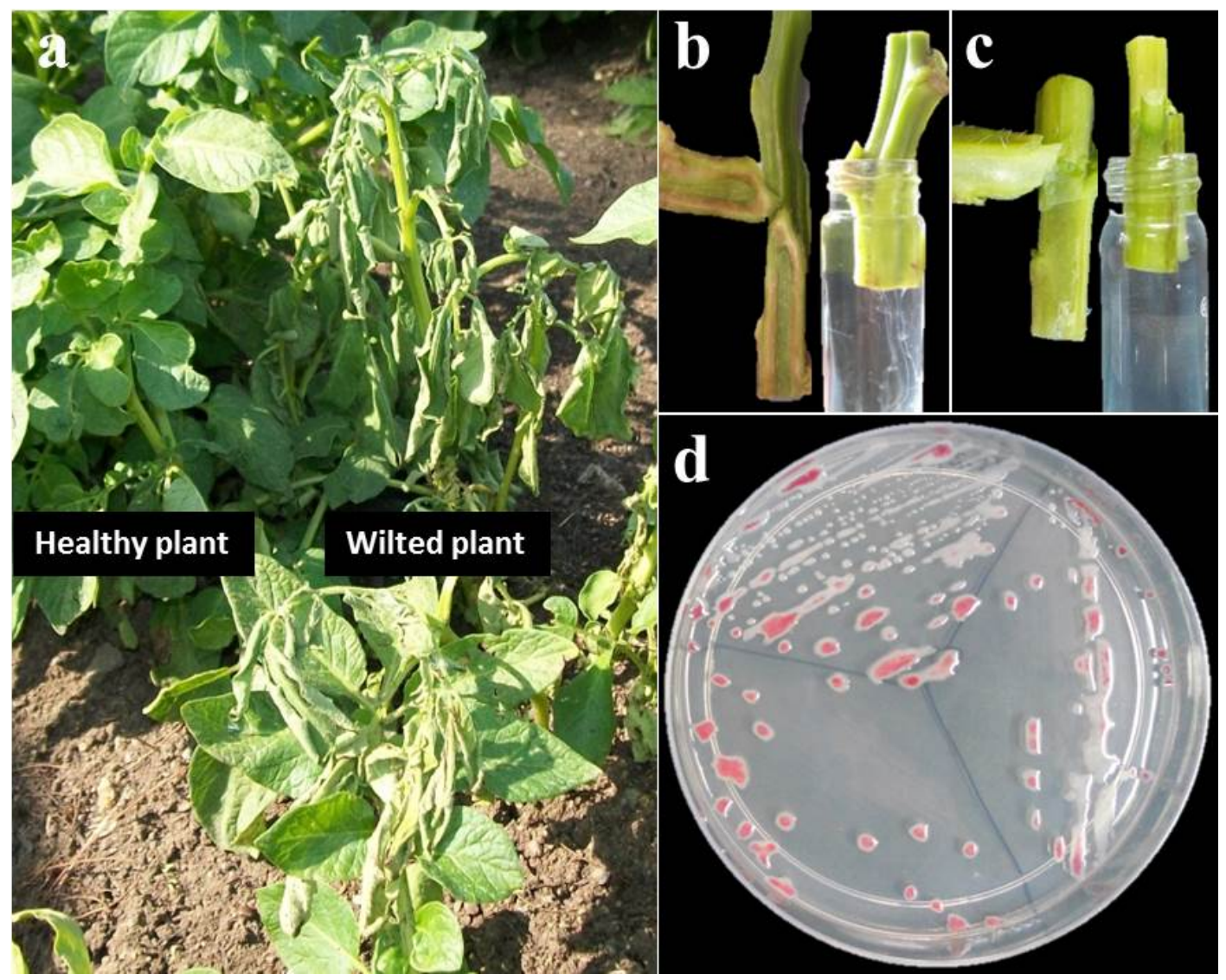

Figure 1. Symptoms of bacterial wilt of potato caused by $R$. solanacearum (a); brown discoloration of vascular tissues in stem and bacterial streaming in clear water from stem of infected plant (b) in comparison with healthy plant stem (c) and typical $R$. solanacearum colonies on TZC agar medium (d).

(race 2), potato and tomato in temperate conditions (race 3 ), ginger (race 4) and mulberry (race 5) and six biovars related to the ability to metabolize three sugar alcohols and three disaccharides (He et al., 1983). Based on this classification, potatoes are known to be affected by two races of $R$. solanacearum, that is, race 3 inducing wilt of potatoes under cool temperate conditions and race 1 damage potato crops under tropical and subtropical conditions (Martin and French, 1985).

Recently, a new phylogenetic classification system was proposed by Fegan and Prior (2005), consisting of four phylotypes, each further divided into sequevars. By using the $R$. solanacearum species-specific primers $759 / 760$ in combination with phylotype-specific primers (Nmult:21: 1F, Nmult:21:2F, Nmult:23:AF, Nmult:22: InF, and Nmult: 22:RR), species and phylotype affiliation can be simultaneously identified in a single PCR assay, called the phyloptype-specific multiplex PCR (Pmx-PCR). Depending on Pmx-PCR product patterns, strains of $R$. solanacearum can be grouped into the four phylotypes. Phylotype I (Asiatic origin) is characterised by production of 280 and 144 bp amplicons. Phylotype II strains (American origin) produce 280 and 372 bp amplicons. Phylotype III (mainly from Africa and nearby islands such as Reunion and Madagascar) produce 280 and $91 \mathrm{bp}$ amplicons. Phylotype IV strains (from Indonesia, Japan, and Australia) produce 280 and $213 \mathrm{bp}$ amplicons. The phylotyping scheme adds valuable information about the geographical origin and in some cases the pathogenicity of strains. Therefore, the present investigation was aimed to use phylotyping scheme to determine the phylotypes of the $R$. solanacearum strains causing potato bacterial wilt in Hassan and Chikmagalur districts of Karnataka state in India.

\section{MATERIALS AND METHODS}

\section{Bacterial strains, media and growth condition}

A total of 15 strains of $R$. solanacearum were isolated from bacterial wilt affected potato plants (Figure 1a) collected from potato growing regions of Hassan and Chikmagalur districts of Karnataka in India during Kharif 2011 season. Stem pieces (5-6 cm long) of wilted potato plants were collected from each field, washed thoroughly, air dried and brought to the laboratory for further studies. The samples were then surface disinfected with $70 \%$ ethanol, peeled, sub sampled and macerated in sterile distilled water. Macerates were streaked on Kelman's triphenyltetrazolium chloride (TZC) agar medium 
Table 1. List of primers used for multiplex PCR.

\begin{tabular}{llcl}
\hline Primer Name & Primer sequence & Expected band size (bp) & Remark \\
\hline Nmult:21:1F & 5'-CGTTGATGAGGCGCGCAATTT-3' & 144 & Phylotype I (Asiaticum) \\
Nmult:21:2F & 5'-AAGTTA TGGACGGTGGAAGTC-3' & 372 & Phylotype II (Americanum) \\
Nmult:22:InF & 5'-ATTGCCAAGACGAGAGAAGTA-3 & 213 & Phylotype IV (Tropical) \\
Nmult:23:AF & 5'-ATTACGAGAGCAATC GAAAGATT-3' & 91 & Phylotype III (African) \\
Nmult:22:RR & 5'-TCGCTTGACCCTATAACGAGTA-3 & & Amorce reverse unique \\
$759 R$ & 5'-GTCGCCGTCAACTCACTTTCC-3' & & Universal R. solanacearum \\
$760 F$ & 5'-GTCGCCGTCAGCAATGCGGAATCG-3' & 280 & specific primers \\
\hline
\end{tabular}

(Kelman, 1954) (Peptone, $10 \mathrm{~g}$; glucose, $2.5 \mathrm{~g}$; Casamino acid, $1 \mathrm{~g}$; agar, $18 \mathrm{~g}$; TZC, $\left.50 \mathrm{mg} \mathrm{L}^{-1} ; \mathrm{pH} 7.0-7.1\right)$. Plates were incubated at $28 \pm 2^{\circ} \mathrm{C}$ for 48 to $72 \mathrm{~h}$. Bacterial colonies developing the typical irregular mucoid colonies were again streaked onto fresh TZC medium for further purification. Well separated typical wild type $R$. solanacerarum colonies were further transferred to medium modified by exclusion of TZC for multiplication of inoculum. Two loops of bacterial culture were then transferred in $2 \mathrm{ml}$ of double distilled sterile water and the cultures were stored at $20 \pm 2^{\circ} \mathrm{C}$.

\section{DNA extraction from bacterial strains}

Total genomic DNA was extracted as described by Chen and Kuo (1993). A well separated bacterial colony on TZC agar was used to inoculate $1.5 \mathrm{ml}$ of CPG broth (Peptone, $10 \mathrm{~g}$; glucose, $2.5 \mathrm{~g}$; Casamino acid, $1 \mathrm{~g}$; distilled water 1 litre; $\mathrm{pH} 7.0-7.1$ ) in $2.0 \mathrm{ml}$ Eppendorf tubes. The cultures were grown at $28 \pm 2^{\circ} \mathrm{C}$ for $48 \mathrm{~h}$ with vigorous shaking. Each culture $(1.5 \mathrm{ml})$ was harvested by centrifugation for $3 \mathrm{~min}$ at $13,000 \mathrm{xg}$. The cell pellet was re-suspended and lysed in $300 \mu \mathrm{l}$ of lysis buffer $(40 \mathrm{mM}$ Tris-acetate $\mathrm{pH} 7.8,20 \mathrm{mM}$ sodium-acetate, $1 \mathrm{mM}$ EDTA, $1 \%$ SDS, $20 \mu \mathrm{g}$ RNase A) by vigorous pipetting and incubated for $30 \mathrm{~min}$ at $37^{\circ} \mathrm{C}$. To remove most proteins and cell debris, $100 \mu \mathrm{l}$ of $5 \mathrm{M} \mathrm{NaCl}$ solution was added and mixed well, and then the viscous mixture was centrifuged at 13,000 $\mathrm{xg}$ for $10 \mathrm{~min}$ at $4^{\circ} \mathrm{C}$. After transferring the clear supernatant into a new vial, an equal volume of chloroform was added, and the tube was gently inverted at least 50 times when a milky solution was completely formed. Following centrifugation at $13,000 \mathrm{xg}$ for $3 \mathrm{~min}$, the extracted supernatant was transferred to another vial and the DNA was precipitated with $100 \%$ ethanol, washed twice with $70 \%$ ethanol, dried in speed-vacuum, and re-dissolved in $50 \mu \mathrm{l}$ of TE buffer.

\section{Phylotype analysis}

Phylotype identification of each strain was done as described (Fegan and Prior, 2005; Prior and Fegan, 2005). Phylotype specific multiplex PCR (Pmx-PCR) was carried out in $25 \mu \mathrm{l}$ final volume of reaction mixture, containing $1 \times$ Taq Master Mix (PCR buffer, $1.5 \mathrm{mM}$ $\mathrm{MgCl}_{2}, 200 \mu \mathrm{M}$ of each dNTP, $50 \mathrm{mM} \mathrm{KCl}, 10 \mathrm{mM}$ Tris- $\mathrm{HCl}$ and $1.25 \mathrm{U}$ of Taq DNA polymerase.), 6 pmoles of the primers Nmult: 21 : $1 \mathrm{~F}$, Nmult:21:2F, Nmult:22:InF, 18 pmoles of the primer Nmult:23: AF and 4 pmoles of the primers 759 and 760 (Opina et al., 1997) (Table 1). The following cycling programme was used in a thermal cycler (Gen-AmpR PCR System 9700 of M/S Applied Biosystem): $96^{\circ} \mathrm{C}$ for $5 \mathrm{~min}$ and then cycled through 30 cycles of $94^{\circ} \mathrm{C}$ for $15 \mathrm{~s}$, $59^{\circ} \mathrm{C}$ for $30 \mathrm{~s}$ and $72^{\circ} \mathrm{C}$ for $30 \mathrm{~s}$, followed by a final extension period of $10 \mathrm{~min}$ at $72^{\circ} \mathrm{C}$. A $5 \mu \mathrm{l}$ aliquot of each amplified PCR product was subjected to electrophoresis on $2 \%$ agarose gel, stained with ethidium bromide and bands were visualized on a UV-transillumi-nator. This Pmx-PCR amplifies the 280-bp "universal" $R$. solanacearum specific reference band plus following phylotype-specific PCR products: a 144-bp amplicon from phylotype I strains; a 372- bp amplicon from phylotype II strains; a 91-bp amplicon from phylotype III strains; and a 213-bp amplicon from phylotype IV strains.

\section{RESULTS AND DISCUSSION}

\section{Bacterial strain collection and their identification}

During the present studies, bacterial wilt infected potato stems were collected in Kharif 2011 season from wilt affected areas of Hassan and Chikmagalur districts of Karnataka state. A total of 15 bacterial strains were recovered from wilt affected potato stems. On Kelman's (1954) TZC agar medium, these strains yielded typical virulent type colonies, which were cream coloured, irregularly shaped, highly fluidal with pink pigmentation in the centre (Figure 1d). These characters were consistent with $R$. solanacearum as described by Kelman (1954) on TZC agar medium. Total genomic DNA of all the strains was extracted and subjected to PCR amplification using the $R$. solanacearum specific universal primer pair 759/760. An expected single 280-bp fragment (Opina et al., 1997) amplified in all the strains (Figure 2), which further confirmed the identity of these strains as $R$. solanacearum.

\section{Phylotype identification}

Phylotype specific multiplex PCR revealed that all the fifteen strains from Karnataka belonged to phylotype I as a 144-bp amplicon was observed in all the strains when Pmx-PCR products of these strains were subjected to electrophoresis on $2 \%$ agarose gel (Figure 3 ). Phylotype I strains causing bacterial wilt of potato includes $R$. solanacearum strains traditionally classified as biovar 3,4 and 5; are primarily isolated in Asia (Fegan and Prior, 2005 ) and correspond to race 1 of the pathogen. Also, $R$. solanacearum strains which cluster into phylotype I encompass a majority of lowland (tropical) strains with a wide host range (Cellier and Prior, 2010). Shekhawat et al. (1978) have also reported race 1 biovar 3 of $R$. solanacearum as cause of bacterial wilt of potatoin in plains and plateau region of India and our results are in conformity with this. 


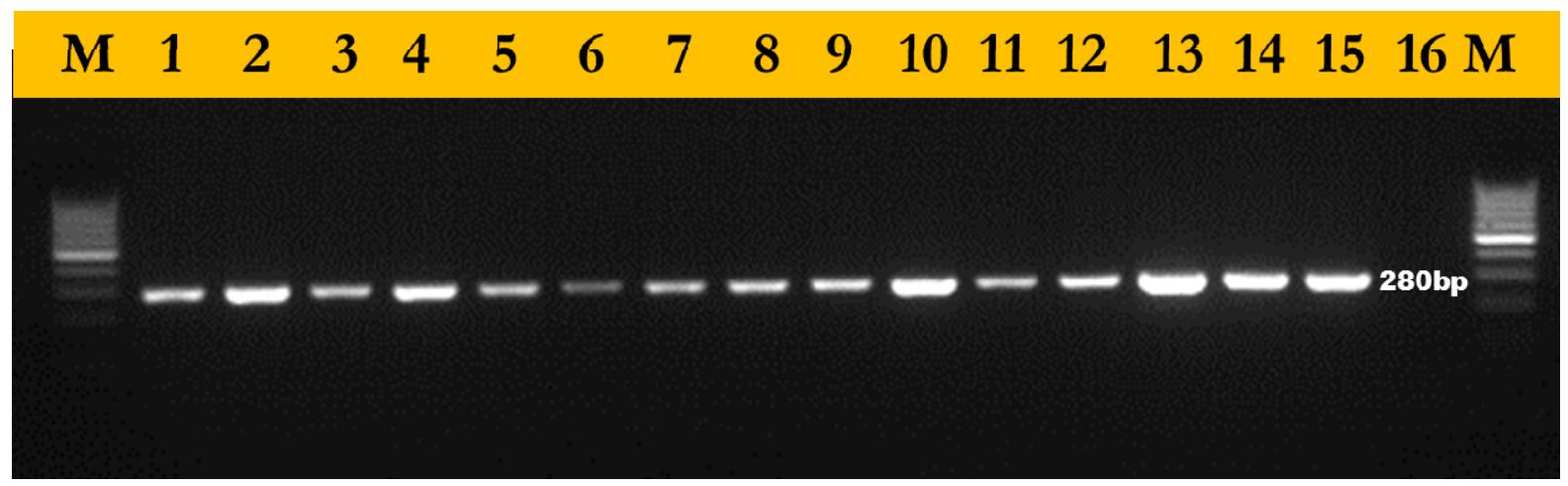

Figure 2. Single 280-bp fragment resulting from PCR amplification using $R$. solanacearum specific universal primer pair $759 / 760$ (Lane $M=1 \mathrm{~kb}$ ladder, lane 1-15 = strains of $R$. solanacearum, lane $16=$ control).

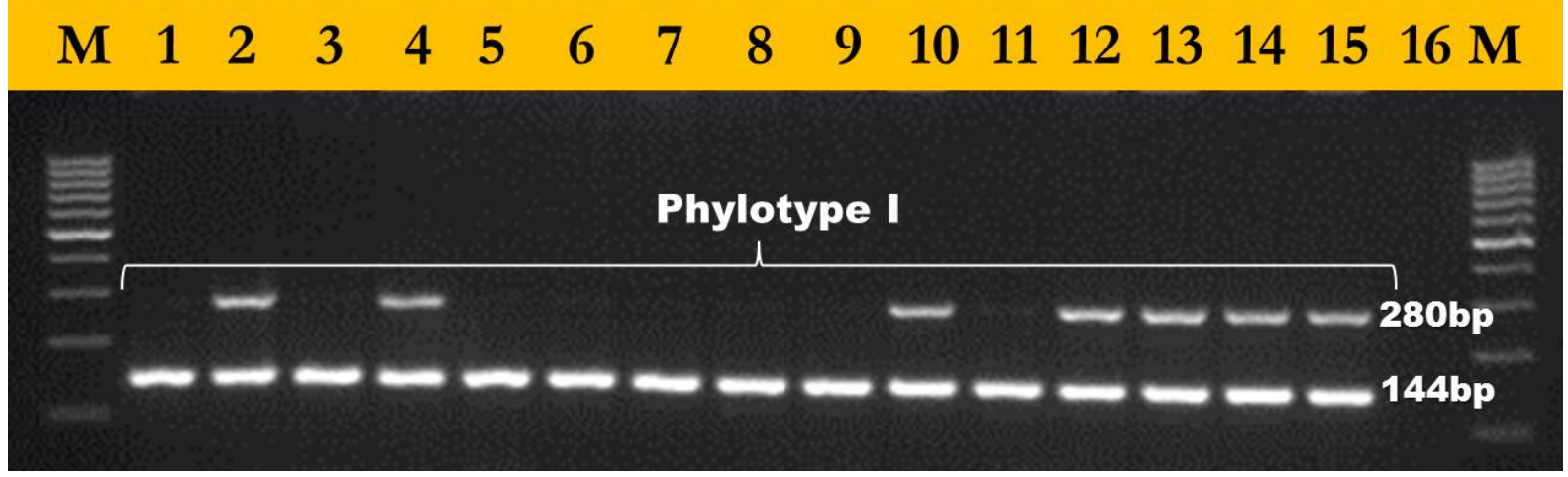

Figure 3. Phylotype specific multiplex PCR of 15 isolates of $R$. solanacearum from Karnataka (Lane $M=1 \mathrm{~kb}$ ladder, lane $1-15=$ strains of $R$. solanacearum, lane $16=$ control).

Knowledge of local pathogen diversity is a key prerequisite for successful integrated disease management programme. Varieties known to be resistant to strains of one phylotype of $R$. solanacearum may become susceptible to strains of other phylotype of $R$. solanacearum (Suga et al., 2013). In Hassan and Chikmagalur districts of Karnataka state, bacterial wilt of potato is caused by strains of phylotype I of $R$. solanacearum (this study). These phylotype I strains are different from those reported recently by Sagar et al. (2014) as cause of bacterial wilt of potato in Madhya Pradesh (phylotype II strains), West Bengal (phylotype II strains) and in Meghalaya (phylotype II and IV strains) states in India. Race 3 biovar 2 (phylotype II strains) is primarily pathogenic to potato and persist only under cool humid conditions whereas, race 1 (phylotype I strains) have wide host range and survive in warm areas (Shekhawat et al., 1992). While the occurrence of phylotype II strains in warm sub-tropical climatic conditions in India is attributed to latently infected tubers (Sagar et al., 2013), phylotype I strains are anticipated to cause bacterial wilt of potato in low land (tropical) areas (Martin and French, 1985; Shekhawat et al., 1992).

\section{Conclusion}

Bacterial wilt disease of potato is caused by strains of phylotype I of $R$. solanacearum in Karnataka which differ from strains of $R$. solanacearum in Madhya Pradesh, West Bengal and Meghalaya states in India. The occurrence of Phylotype I of $R$. solanacearum in Karnataka may be attributed to the climatic condition and cropping pattern in the state. Particularly in Hassan and Chikmagalur districts, potato crop is grown in rotation with other solanaceous vegetables like tomato, brinjal, etc. This helps in perpetuation of this particular phylotype which also has wide host range and survive better in tropical climate. Phylotype I strains correspond to race 1 of the pathogen and cause potato bacterial wilt in low land (tropical) areas.

\section{Conflict of Interests}

The author(s) have not declared any conflict of interests.

\section{ACKNOWLEDGEMENT}

The authors are grateful to Dr. B. P. Singh, Director, Central Potato Research linstitute (ICAR), Shimla -171 001 
(H.P.), India, for providing necessary facilities during the course of this study.

\section{REFERENCES}

Anonymous (2011). Annual Report, 2010-11, Project Coordinator Unit, Central Potato Research Institute, Shimla, India: pp. 369-381.

Basvaraja N, Siddagangaiah S, Naik KR, Kavitha KR, Naik KS, Khan HIS, Chandravathi B (2009). Karnataka. Region Specific Technology for Potato Production in India. In, AICRP (Potato) Bulletin-3. PS Naik and SS Lal (Eds). Central Potato Research Institute, Shimla, India: pp. 64-75.

Cellier G, Prior P (2010). Deciphering phenotypic diversity of Ralstonia solanacearum strains pathogenic to potato. Phytopathol. 100:12501261.

Chen WP, Kuo TT (1993). A simple and rapid method for the preparation of Gram-negative bacterial genomic DNA. Nucleic Acids Res. 21:2260.

Elphinstone JG (2005).The current bacterial wilt situation: a global overview. In, Bacterial wilt disease and the Ralstonia solanacearums pecies complex.C Allen, P Prior, ACHayward (Eds)St. Paul: APS:928.

Fegan M, Prior P (2005). How complex is the "Ralstonia solanacearum species complex". In, Bacterial wiltdisease and the Ralstonia solanacearum species complex. C Allen, P Prior, AC Hayward (Eds) St. Paul: APS: 449-462.

He LY, Sequeira L, Kelman A (1983).Characteristics of strains of Pseudomonas solanacearum.Plant Dis. 67:1357-1361.

Kelman A (1954). The relationship of pathogenicity in Pseudomonas solanacearum to colony appearance on a tetrazolium chloride medium. Phytopathol. 44:693-695.

Martin C, French ER (1985). Bacterial wilt of potato, Pseudomonas solanacearum. Technical Bulletin 13. Lima: International Potato Centre. p. 16.
Opina N, Tavner F, Hollway G, Wang JF, Li TH, Maghirang R, Fegan M, Hayward AC, Krishnapillai V, Hong WF, Holloway BW, Timmis JN (1997). A novel method for development of species and strainspecific DNA probes and PCR primers for identifying Burkholderia solanacearum. Asia Pac. J. Mol. Bio.5:19-30.

Prior P, Fegan M (2005). Recent development in the phylogeny and classification of Ralstonia solanacearum.Acta Horticult. 695:127-136.

Sagar V, Jeevalatha A, Mian S, Chakrabarti SK, Gurjar MS, Arora RK, Sharma S, Bakade RR, Singh BP (2014). Potato bacterial wilt in India caused by strains of phylotype I, II and IV of Ralstonia solnacearum. Eur. J. Plant Pathol.138(1):51-65.

Sagar V, Somani AK, Arora RK, Sharma S, Chakrabarti SK, Tiwari SK, Chaturvedi R, Singh BP (2013). Status of bacterial wilt of potato in Malwa region of Madhya Pradesh in India. J. Plant Pathol. 95:321328.

Shekhawat GS, Singh R, Kishore V (1978).Distribution of bacterial wilt and races and biotypes of the pathogens in India. J. Indian Potato Assoc. 5:155-165.

Shekhawat GS, Chakrabarti SK, Gadevar AV (1992). Potato bacterial wilt in India. Technical Bulletin 38. Central Potato Research Institute, Shimla, India. p. 52.

Suga Y, Horita M, Umekita M, Furuya N, Tsuchiya K (2013). Pathogenic characters of Japanese potato strains of Ralstonia solanacearum. J. Gen. Plant Pathol. 79:110-114.

Yabuuchi E, Kosako Y, Yano I, Hotta H, Nishiuchi Y (1995). Transfer of two Burkholderia and an Alcaligenes species to Ralstonia gen. nov.: proposal of Ralstonia pickettii (Ralston, Palleroni and Douderoff 1973) comb. nov., Ralstonia solanacearum (Smith 1896) comb. nov. \&Ralstonia eutropha (Davis 1969) comb. nov. Microbiol.Immunol. 39:897-904. 